Vol. XVII No. 2

\title{
Museum News
}

\section{By Fred G. Bard, Director, Sask. Museum of Natural History.}

On account of the unseasonably warm and dry weather, by mid April this year the Museum had already become involved in field work, most of which was unexpected. Specimens were collected at several significant paleontological and archaeological sites near Swift Current, Avonlea and Rockglen. Most of this work represents salvage operations.

Programmed field-work includes a three month continuation of the archaeological survey of the South Saskatchewan River Basin. This will be a joint e: pedition of the National Musuem (Ottawa) and our own Museum. Field parties will again be led by Professor William J. MayerOakes (University of Toronto). In addition a separate and similar joint expedition will again search for paleontological materials. Dr. W. Langston (Ottawa) will head this project.

Francis R. Cook (Wolfville, Nova Scotia), will spend the summer in southern Saskatchewan collecting reptiles and amphibians for the National Museum. It is expected that this work will lead to a publication on the distribution and taxonomy of these animals. This is part of our fauna which has been neglected and we urge interested persons to write to Cook in care of the Museum (Regina).

A party from the American Museum of Natural History (New York) will work in northern Saskatchewan, collecting material for a habitat group of Wolverine. T. Donald Carter, Assistant Curator, Dept. of Mammals, will lead this expedition.

Dr. Robert W. Storer (University of Michigan, Museum of Zoology, Ann Arbor, Michigan), former editor of the Auk, has already established himself in the Qu'Appelle Valley near Fort San, where he will study the comparative behaviour of our five species of grebes. Manley Callin has given invaluable advice and assistance in this program. Dr. Bob Nero and Fred Lahrman will spend some time working with Dr. Storer. We wish the latter the best of luck in this undertaking.
At the date of writing (May 2), the Canada Goose Management Program (Wascana Waterfowl Park, Regina) is off to a fine start with geese sitting on 28 nests! This project has attracted the attention of waterfowl managers throughout Canada. It is hoped that similar efforts will be made elsewhere to bring the Canada Goose back to the Canadian prairies.

At the time of writing, Whooping Cranes have started their long flight to their nesting grounds. In a telegram, dated April 3, Claude F. Lard, Refuge manager at Aransas, reported that "an aerial flight over area disclosed only 21. Whooping Cranes. Evidently, 11 have departed for breeding grounds." A final telegram, dated April 27, reports "an aerial flight this afternoon disclosed that all Whooping Cranes have departed."

On April 14, Mrs. George Williams, Goodwater, Sask. (school teacher) sighted four Whooping Cranes, which were also observed by P.F.R.A. men in the area. A field check by Fred Lahrman and myself on April 14 revealed $3000+$ Sandhills at the north end of Last Mountain Lake, but no Whooping Cranes were observed.

Professor K. J. McCallum, University of Saskatchewan, Chemistry Department, has announced results of a Carbon-14 test of one sample of wood from the middle level of the Scrimbit Forest site (see Blue Jay, March, 1959). The date of $9500 \pm 500$ years conforms to previous estimates for this post-glacial forest site.

\section{IRPORTANT 1959 DATES TO REMEMBER}

June 12-14, Summer Meeting of the Saskatchewan Natural History Society at Moose Mountain.

August 25-30, Annual Meeting and Field Trip of the American Ornithologists' Union in Regina.

October, Annual Meeting of the Saskatchewan Natural History Society in Moose Jaw. 